\title{
LEVEL OF ADOPTION OF QUALITY MANAGEMENT SYSTEMS INTO THE MEXICAN PORK INDUSTRY
}

\author{
Ema Maldonado-Siman ${ }^{1, *}$, Agustín Ruíz-Flores ${ }^{1}$, Rafael Núñez- \\ Domínguez $^{1}$, Mariano González-Alcorta ${ }^{1}$, Bertha Alicia Hernández- \\ Rodríguez $^{1}$ \\ ${ }^{1}$ Posgrado en Producción Animal. Universidad Autónoma Chapingo. Km. 38.5 Carretera \\ México-Texcoco. 56230. Texcoco, Edo. de México. \\ * Corresponding author, Address: Posgrado en Producción Animal, Universidad Autónoma \\ Chapingo. Km. 38.5 Carretera México-Texcoco. 56230. Texcoco, Edo. de México, Tel: \\ +52-(595)95216-21,Fax:+52-(595)95216-89,Email: emamaldonado@correo.chapingo.mx
}

Abstract: This research studies the characteristics of the Mexican pork sector; adoption status of quality management systems, and product destinations. Ninety six percent of fifty enterprises have fully answered a questionnaire. Ninety percent are small and medium-sized, the rest are large-sized firms. Nineteen percent of them have totally adopted HACCP, sixty three percent are implementing or planning to do it, the rest have no plans to adopt it. Thirteen percent of the enterprises had ISO 9000. Thirty four percent of their sales go to supermarkets, $57 \%$ to other retail chains and $9 \%$ to exportation. Product destinations are mainly Central America, United States of America, Asia and Mexico. To improve efficiency and the quality of process it is necessary to implement HACCP. Besides, customers and legal requirements are the external factors, which result in this adoption. In the process of implementing, there are some problems, such as staff motivation and training. The results suggest that HACCP system operating is important for the Mexican pork industry. It also has relevant implications in domestic trade. It is necessary to encourage adoption of quality management systems in the sector.

Keywords: $\quad$ Mexican Pork industry, HACCP, ISO 9000

Please use the following format when citing this chapter:

Maldonado-Siman, E., Ruíz-Flores, A., Núñez-Domínguez, R., González-Alcorta, M. and HernándezRodríguez, B.A., 2009, in IFIP International Federation for Information Processing, Volume 295, Computer and Computing Technologies in Agriculture II, Volume 3, eds. D. Li, Z. Chunjiang, (Boston: Springer), pp. 1747-1756. 


\section{INTRODUCTION}

Food safety is the major focus of consumers, producers, industry groups and government agencies in the whole world. Sockett (1996) indicates that meat is an important agent of food-borne infections. However, consumers assume that safety in pork meat is crucial to reduce outbreak trends of human illness in domestic and foreign countries. The field of pork production has recognized the importance of having consumer's confidence in the pork product by offering a safe product. In order to obtain this consumer's recognition, food safety is an essential coordination of efforts throughout the food chain (Lautner, 2005). This means that research programs in production, processing, distribution, retail and consumer, need to be developed.

In general, it is accepted that Quality Management Systems (QMS) are the most effective means of ensuring the safety and quality of food that identify a series of food attributes (Caswell et al., 1998). The most important QMS in the food industry is HACCP (Hazard Analysis and Critical Control Points), which is now mandatory in some industries and countries, and ISO 9000 which is no mandatory. HACCP focuses to reduce food borne hazards throughout the food supply chain (FSIS, 1996; Hathaway and Cook, 1996) and ISO 9000 aims to standardize quality management and to facilitate communication in a set of international quality assurance standards that guarantee a consistent production process (Bredahl et al., 1997).

It is evident that implementation of HACCP within the Mexican pork industry sector has become widespread over last several years (Gallardo, 2005), and it is beneficial to the firm. Mexican meat industry includes Federal Inspection Type (TIF) enterprises that carry out slaughter domestic animals and/or diverse transformation processes. Food quality in these Mexican TIF enterprises is supervised by the Ministry of Agricultural, Livestock, Rural Development, Fisheries and Food (SAGARPA). These plants incorporate new control points for materials used to handle residues and to detect possible causes of ecological contamination (DGG-CEA, 2000). In addition, the National Food Safety and Quality Program (Programa Nacional para la Inocuidad y Calidad Alimentaria- PRONINCA) promote the implementation of HACCP in the processing and handling of fresh vegetables and meat processing and handling (SAGARPA, 2000).

On the other hand, Holleran and Bredahl (1997) developed a conceptual outline in order to analyze food safety. They observed that firms were motivated by internal and external factors when implementing ISO 9000. It was also found that ISO 9000 was particularity adopted by large firms due to internal operating efficiency and cost reduction. Alternatively, intra - and inter-firm factors are registered in adopting QMS such as HACCP and ISO 
9000 (Fouayzi et al., 2005). Price premiums for better quality products, efficiency and improved management are included into the intra-firms factors, whilst inter-firm factors incorporated the improvement of the ability to identify other firms into the supply chain and better opportunities of having trade with them. The objectives of this paper are to characterize the Mexican pork sector, to explore the adoption status of Quality Management Systems (QMS) such as HACCP and ISO 9000, and to identify the reasons and problems faced by the enterprises to implement the systems and product destination.

\section{MATERIALS AND METHODS}

The data used in this study comes from a survey of firms in pork processing industry (Henson et al., 1999; Maldonado et al., 2005). The survey includes a series of questions intended to collect information about firm characteristics, customers and products, and the status of adoption of QMS as well as other relevant elements, such as the importance of factors in the decision to develop/ implement these two QMS and problems faced by the enterprises during the implementing process. Survey data is collected by direct interview of the General Manager and the Veterinarian assigned of each Pork Meat Federal Inspection Type (TIF) enterprises registered in the Official Listing of TIF Enterprises of the Ministry of Agriculture, Livestock, Rural Development, Fisheries and Food (SAGARPA) from 2000 to 2001. The enterprises were revisited or phoned in 2003 to validate the accuracy of the information given in the questionnaire.

Respondents are presented with a list of factors that previous studies suggested can motivate the decision to implement QMS such as HACCP and ISO 9000 (Martin et al, 1993; Vanguard Consulting, 1993). Then, they are asked to indicate how important each of them have been in their decision, using a seven-point Likert scale ranging from "very important" (1) to "very unimportant" (7).

For the problems faced in the implementation and/or operation of these two QMS, enterprises are also asked to identify the relative importance on a seven-point Likert scale. The scale ranges from "major problem" (1) to "minor problem" (7) of a series of variables that previous studies have suggested can be difficulties in the implementing process of these two QMS (Institute of Quality Assurance, 1991; Tompkin, 1994). Chi-square tests are used to analyze the data using the Statistical Analysis System package (SAS, 2001). 


\section{RESULTS AND DISCUSSION}

All the 50 firms that have answered the survey are members of the National Association of Enterprises Federal Inspection Type (ANETIF - the Trade Association of Meat Industry). Forty-eight (96.0\%) of the questionnaires were fully completed. Twenty enterprises $(41.7 \%)$ had between 51 and 200 employees that represent the size of most of the Mexican Pork TIF processing firms; $33.3 \%$ of the enterprises had between 201 and 500 employees; seven enterprises (14.6\%) had less than 50 employees; and the remaining five (10.4\%) registered more than 500 employees.

Fifty-two percent of the firms are established at the Center region of the country near the cities with heavy domestic trade markets. Forty six percent are settled at the north part where the other main market destination of pork meat products is located. Only $2.1 \%$ are found at the south region. Plants carry out four types of processes, sausage-making activities registered the major production level $(37.5 \%)$, which clusters most of the enterprises; $35.4 \%$ of them were slaughterhouses. The rest of the plants concentrate their activities in prepared meals (6.3\%), and cold cuts and packing (20.8\%).

Additional details about the status of QMS, HACCP and ISO 9000 adoption by firms are presented in Fig. 1. Thirteen of the surveyed firms have two QMS, nine (18.8\%) with HACCP under fully operation and four (8.3\%) with ISO 9000 certification. It seems relevant the adoption of QMS for this group of processing industry. It may perceive benefits from QMS by dealing with other firms with adopted QMS, and having HACCP seems to be common business practice between them. As suggested in the literature, some firms require their suppliers to have QMS in place to reduce transaction costs associated with hesitation about the quality of the product they buy. Five out of nine enterprises with HACCP fully operating (55.6\%) require suppliers to have QMS. Fouayzi et al., (2005) suggested that depending on enterprise position in the chain, it might be required to use specific QMS. Commonly, the leader in the supply chain has the most responsibility for assuring the quality of a product. 


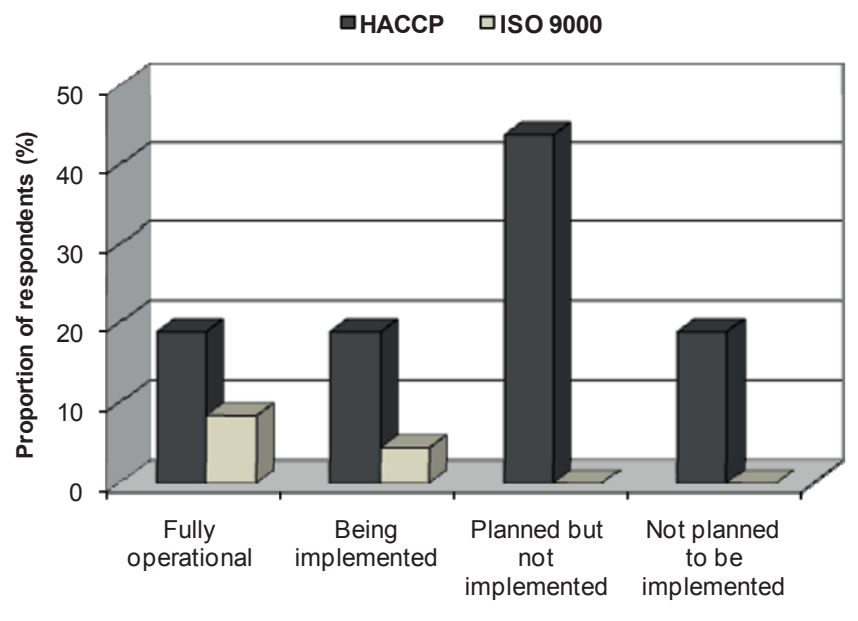

HACCP and ISO 9000 status

Fig. 1: HACCP and ISO 9000 status of plants that responded the survey

Besides, two more enterprises $(4.2 \%)$ had the voluntary standard ISO 9000 in full operation, although the group is also formed for those nine with the status still of being operating HACCP $(18.8 \%)$. This second group declared its interest to be included in the list of regular domestic and foreign suppliers. On the other side, 30 enterprises of pork meat TIF firms have Mexican Official Norms adopted/operating, but any QMS, nevertheless 21 (43.8\%) were on the path of beginning to adopt HACCP system. They were mainly pulling off with structural changes of their plants, optimum staff training, and investment in new equipment. The last group of nine firms pointed out that they have no interest in adopting any QMS. The main factors for the decision are related with high costs of implementing/operating, not being a legal requirement in domestic market and not required by major customers. However, capacity for food safety remains far below international standards, and food safety requirements are considered as a significant barrier (Henson et al., 2000; Henson and Wilson, 2002) to markets of developed countries or even in domestic developing countries.

In the food industry, the supply chain can be represented by producer of raw good, as pork producers, who had recognized the importance of producing a product in which their domestic and international market and consumers could have the highest confidence. Then, the processors followed in this segment of chain can be more than one type. Subsequently, the wholesalers, retailers or caterers may follow and are in charge of selling the final product to consumers. 
Additional details about the percentage of Mexican meat pork production and main market destination of the 48 TIF enterprises surveyed are registered in Table 1. They reported seven destinations for their production. Supermarkets had the highest proportion (35.0\%), 30 firms participated of this proportion of market. This segment of sale chains frequently moves faster in the direction of certification and traceability requirements (Henson and Caswell, 1999), thus the quality control systems are highly required.

Table 1. Percentage of Mexican meat pork production and main marketing destination of the 48 TIF enterprises surveyed.

\begin{tabular}{lccc}
\hline & Frequency & Percentage & Production (\%) \\
\cline { 1 - 3 } Sales destination & & & \\
\cline { 1 - 3 } Supermarkets & 30 & 62.5 & 35.0 \\
Other retailers & 11 & 22.9 & 7.5 \\
Major caterers & 34 & 70.8 & 32.3 \\
Wholesalers & 9 & 18.8 & 7.0 \\
Final consumers & 6 & 12.5 & 1.8 \\
Other food processors & 9 & 18.8 & 7.5 \\
Exportation & 17 & 35.4 & 8.9 \\
Cumulative Frequency/Percentage & & & 100.0 \\
Exportation & & & \\
USA & 9 & 18.8 & 14.4 \\
Asia (Japan, Korea, China) & 10 & 20.8 & 35.1 \\
Puerto Rico & 4 & 8.3 & 10.0 \\
Central America & 10 & 20.8 & 25.8 \\
Cuba & 1 & 2.1 & 5.3 \\
Fast food chains and restaurants & 2 & 4.2 & 9.3 \\
Cumulative Frequency/Percentage & & & 100.0 \\
\hline
\end{tabular}

Major caterers consumed $32.3 \%$ of production, and the largest group of enterprises is working with them. Although 17 firms export, less than $10 \%$ of production is exported. That is, because capacity to implement effective food safety controls is of vital importance to food exports from developing countries. Henson and Wilson (2002) indicate that the exporting country must be able to comply with food safety requirements and to demonstrate that compliance has been achieved.

Six export destinations are related with this pork processing companies (Table 1). They reported that most of their production (35.1\%) is shipped to Japan, Korea and China, however only ten firms share this trading relationship. There may be a couple of reasons to endorse the fact; it could mean the number of TIF pork slaughterhouses have improved their infrastructure and processing technology in 2001 due to financial support. However, through 2002 the increased trends of ten years of exportation went 
down because major foreign marketing competence from USA and Brazil, and higher food safety standards took place in Japan (Gallardo, 2005).

Central America is the second destination for the Mexican pork meat (25.8\%). It has lower quality standards and requirements. Less than $10 \%$ of the production goes to USA market; only nine Mexican enterprises participated of this market share. Henson et al., (2000) stated the necessity of the application of HACCP and other hygienic practices along the meat production chain when the goal is to export to most developed countries such as the USA. Those countries need a proof that food safety requirements are achieved. Domestic market with specific high pricing niches has $9.3 \%$ of the production and only two enterprises report relationship with them. Local markets in Latin America countries with these characteristics affect local producers by imposing quality and safety standards on them (Reardon and Berdegué, 2002).

Concerning the reasons to implement QMS, the overall analysis showed a difference $(\mathrm{P}<0.0001)$ whether they were regarded as of major or minor importance by the industries. Improvement of product quality, the need of the plant to be third party accredited, and attraction of new customers for products were considered the major incentives for the enterprises (Table 2). The enterprises are interested in improving their product quality because the increased competence both at domestic and international levels. In addition, the firms third party accredited are able to export, and as consequence, they might attract new customers for their products. The results of this study are similar to those found by Deodhar (2003) for the Indian Food Processing Industry and by Semos and Kontogeorgos (2007) in northern Greece. On the other side, reduce product wastage, reduce customer complaints, and recommended by trade organization were reasons considered of minor importance. Since most of the enterprises are domestic market oriented, the compliment with a trade organization recommendation is not in their priorities: In a study in India, Deodhar (2003) reported that recommended by trade organization, and consignment rejection/retention were rated the lowest among all food categories and among all reasons in motivating adoption of HACCP. Similarly, Semos and Kontogeorgos (2007) found that reduced product wastage, reduced production costs, and increased product prices were the least important benefits of operating HACCP.

The overall analysis for problems perceived by the industries in implementing QMS showed a difference $(\mathrm{P} \leq 0.0038)$ whether they were regarded as of major or of minor importance (Table 3 ). Need to retrain both production staff and supervisory/management staff, and reduced staff time available for other tasks were considered as major problems. The low level of formal education, staff labour desertion, and the perception of being lowpaid are cited among the reasons for these problems. 
Table 2. Classification of incentives in implementing Quality Management Systems into the Mexican pork industry.

\begin{tabular}{lcccc}
\hline \multicolumn{1}{c}{ Incentives } & $\mathrm{I}^{\mathrm{a}}$ & $\mathrm{II}^{\mathrm{b}}$ & Percentage $^{\mathrm{a}}$ & Percentage $^{\mathrm{b}}$ \\
\hline To meet the needs of major customers & 21 & 17 & 55 & 45 \\
To meet legal requirements & 22 & 10 & 69 & 31 \\
Improve control of your production process & 24 & 10 & 71 & 29 \\
Reduce product wastage & 11 & 25 & 31 & 69 \\
Reduce customer complaints & 11 & 23 & 32 & 68 \\
Improve efficiency/ profitability of the plant & 26 & 9 & 74 & 26 \\
Improve product quality & 31 & 6 & 84 & 16 \\
Recommended by trade organization & 14 & 23 & 38 & 62 \\
Reduce need for quality audits by customers & 17 & 19 & 47 & 53 \\
Needed for plant to be third party accredited & 28 & 7 & 80 & 20 \\
Generally regarded as good practice & 25 & 10 & 71 & 29 \\
Hold onto existing customers for products & 28 & 10 & 74 & 26 \\
Attract new customers for products & 27 & 7 & 79 & 21 \\
Access new overseas markets & 22 & 15 & 59 & 41 \\
\hline
\end{tabular}

${ }^{a} I=$ major incentive, ${ }^{b} I I=$ minor incentive

Table 3. Problems faced in implementing Quality Management Systems into the Mexican pork industry

\begin{tabular}{lcccc}
\hline \multicolumn{1}{c}{ Problem } & $\mathrm{I}^{\mathrm{a}}$ & $\mathrm{II}^{\mathrm{b}}$ & Percentage $^{\mathrm{a}}$ & Percentage $^{\mathrm{b}}$ \\
\hline Need to retrain production staff & 8 & 0 & 100 & 0 \\
Need to retrain supervisory/managerial staff & 5 & 1 & 83 & 17 \\
Attitude/motivation of production staff & 5 & 4 & 56 & 44 \\
Attitude/motivation of supervisory/managerial staff & 2 & 4 & 33 & 67 \\
Reduced flexibility of production staff & 5 & 3 & 63 & 38 \\
Reduced staff time available for other tasks & 6 & 3 & 67 & 33 \\
Recouping cost of implementing HACCP & 3 & 3 & 50 & 50 \\
Reduced flexibility to introduce new products & 3 & 5 & 38 & 63 \\
\hline
\end{tabular}

${ }^{a} I=$ major problem, ${ }^{b} I I=$ minor problem

The results of this research are similar to those found by Deodhar (2003) in a study in India. In an another study, Semos and Kontogeorgos (2007) found that need to retrain production staff, attitude/motivation of production staff, and reduced flexibility of production process were the main difficulties faced during HACCP operation in northern Greece. Meanwhile, attitude/motivation of supervisory staff, and reduced flexibility to introduce new products were considered as minor problems by the firms surveyed. However, in general, there were no incentives or formal programs for increasing staff motivation. Similarly, in India Deodhar (2003) found that attitude/motivation of supervisory/managerial staff, and reduced flexibility to introduce new products were regarded as less important by the enterprises surveyed. Semos and Kontogeorgos (2007) reported similar results in a survey to northern Greece food companies. 


\section{CONCLUSION}

The study reports the particular characteristics of the Mexican pork TIF industry and destination of their production, and provides indications of internal and external incentives and problems associated with the implementation of HACCP and ISO 9000. The HACCP operation has been a respond to requests of international markets and very specific domestic niches, and less for local public demand. However, this industry needs to go ahead, in order to compete with foreign markets with higher quality products into a globalization trade holding higher rigorous standards. This kind of information is useful for understanding the key factor of QMS adaptation in Mexican pork industry. They can be a tool for improving management and production efficiency along the meat production chain, in order to compete onto domestic and foreign markets, where the demand of quality products is increasing.

\section{REFERENCES}

A. Semos, A. Kontogeorgos. HACCP implementation in northern Greece: Food companies' perception of costs and benefits. British Food Journal, 2007, 109:5-19.

B. Lautner. HACCP- Its Application for the Pork Industry. National Pork Producers Council. 2005-.Available at: http://www.cvm.uiuc.edu/HACCP/Symposium/LAUTNER.HTM

DGG-CEA (Dirección General de Ganadería y Centro de Estadística Agropecuaria). Situación actual y perspectiva de la producción de carnes en México 1990-2000. Elaborado por el Centro de Estadística Agropecuaria y la Dirección General de Ganadería y el apoyo del Departamento de Agricultura de los Estados Unidos de América (USDA). México, D. F. 2000.

E. Holleran, M. E. Bredahl. Food safety, transaction costs, and institutional innovation in the British food sector. Working Paper 97-1, Center for International Trade Studies. Missouri University. Columbia, MO. 1997.

FSIS. Pathogen reduction: Hazard Analysis and Critical Control Point (HACCP) systems; Final Rule. Federal Register. 61(144), 38805-38889. Food Safety Inspection Service. United States Department of Agriculture, Washington, D. C. 1996.

H. Fouayzi, J. A. Caswell, N. H. Hooker. Motivations of Fresh-Cut Produce Firms to Implement Quality Management Systems. Review of Agricultural Economics, 2005, 28:132-146.

Institute of Quality Assurance (IQA). An IQA survey on the use and implementation of BS 5750 standards by third party assessment bodies as seen by the end user". Institute of Quality Assurance. London, U. K. 1991.

J. A. Caswell, M. E. Bredahl, N. H. Hooker. How Quality Management Metasystems are affecting the Food Industry. Review of Agricultural Economics, 1998, 20:547-557.

M. E. Bredahl, E. Holleran, L. Zaibet. ISO 9000 in the UK Food Sector. Working Paper 97-2. Center for International Trade Studies, Missouri University, Columbia, MS. 1997.

N. J. Gallardo. Situación actual y perspectivas de la producción de carne de porcino en México 2005. Coordinación General de Ganadería. Secretaría de Agricultura, Ganadería, 
Desarrollo Rural, Pesca y Alimentación. 2005. Available at: http://www.sagarpa.gob.mx/Dgg/estudio/sitpor05.pdf

P. N. Sockett . The epidemiology and costs of diseases of public health significance, in relation to meat and meat products. Journal Food Safety, 1995, 15: 91-112.

R. B. Tompkin. HACCP in the meat and poultry industry. Food Control, 1994, 5:153-161.

S. A. Martin, B. J. Bowland, B. Calingaert, N. Dean. Economic analysis of HACCP procedures for the seafood industry. North Carolina. Research Triangle Institute. 1993.

S. E. Maldonado, S. J. Henson, J. A. Caswell, L. A. Leos, P. A. Martinez, G. Aranda, J. A. Cadena, 2005. Cost-benefit analysis of HACCP implementation in the Mexican meat industry. Food Control, 2005, 16:375-381.

S. Hathaway, R. L. Cook. A regulatory perspective on the potential uses of microbial risk assessment in international trade. Paper presented at the Second International Conference on Predictive Microbiology Power with Precision. Hobart, Australia. February 18-22, 1996.

S. J. Henson, G. Holt, J. Northen. Cost and benefits of implementing HACCP in the UK dairy processing sector. Food Control, 1999, 10:99-106.

S. J. Henson, J. A. Caswell. Food safety regulation: An Overview of Contemporary Trends. Food Policy, 1999, 24:589-603.

S. J. Henson, J. Wilson. Understanding the nature of sanitary and phytosanitary capacity. World Bank. Washington, D. C. 2002.

S. J. Henson, R. Loader, A. Swinbank, M. Bredahl, N. Lux. Impact of Sanitary and Phytosanitary Measures on Developing Countries. University of Reading. Centre for Food Economics Research. Reading, U. K. 2000.

S. Y. Deodhar. Motivation for and cost of HACCP in Indian food processing Industry. Indian Journal of Economics and Business, 2003, 2:193-208.

SAGARPA (Secretaría de Agricultura, Ganadería, Desarrollo Rural, Pesca y Alimentación). Programa nacional para la inocuidad y calidad (PRONICA). México, D. F. 2000.

SAS. 2001. SAS/STAT User's Guide (Release 8.2). Cary NC, USA: SAS Inst. Inc.

T. Reardon, J. A. Berdegué. The Rapid Rise of Supermarkets in Latin America: Challenges and Opportunities for Development. Development Policy Review, 2002, 20(4): 371-388.

Vanguard Consulting. BS 5750 Implementation and Value Added. Vanguard Consulting, Ltd. Buckingham, U. K. 1993. 